\title{
On Building a Specialized Chinese-English /English-Chinese Electronic Dictionary for Chinese Business English Learners*
}

\author{
Zhiyi Zhou \\ Guangdong University of Foreign Studies, Canton, China
}

\begin{abstract}
Based on needs analysis, this paper studies the needs of Business English (BE) learners on acquiring business terms. An online questionnaire was conducted on full-time undergraduate business English majors and international business majors in the School of International Business English at Guangdong University of Foreign Studies and 254 valid questionnaires were collected. The finding shows that a customized specialized $\mathrm{C}$-E/E-C electronic dictionary is in great need during the 4-year-learning process of BE learners, while disadvantages of existing C-E/E-C electronic dictionaries are spotted. According to the data collected from the survey, author discuss the disadvantages of existing Chinese-English/English-Chinese (C-E/E-C) electronic dictionaries and tries to put forward improvement suggestions on building a specialized C-E/E-C electronic dictionary from the perspective of $\mathrm{BE}$ learners. This research will help business-English- term teaching and specialized C-E/E-C electronic dictionary compiling.
\end{abstract}

Index Terms — needs analysis, electronic dictionary, Business English term, Business English learner

\section{INTRODUCTION}

"In 2006, Business English was approved by the Ministry of Education as an undergraduate major. Since then, Business English major has been successively introduced into 216 colleges and universities in China" (Zhong et al., 2015, p.4). From then on, Business English (BE) related researches, accordingly, have always been hot topics, of which the study of BE dictionary is a significant part. The BE learners mentioned in this paper mainly refer to full-time undergraduate BE major students in China. "The first two years of BE major students are filled with intensive English teaching and training courses with business background teaching materials so that the BE program can equip students with knowledge and skills of English, and meanwhile, pave the way for the next stage of business-course teaching in English" (Zhang, 2011, p.9) After the English learning and training courses of the first two years, majority of BE learners may have laid a solid foundation of general English knowledge and opt to further attach greater importance to the accumulation of business related knowledge in English. Furthermore, electronic dictionary has become a heated trend for both English learner and teacher. Therefore, during this learning process, in which BE learners are going through the middle phase from learning language to acquiring business related knowledge in English, a specialized Chinese-English/English-Chinese (C-E/E-C) electronic dictionary that can serve as an encyclopaedia for them to acquire business related knowledge is in great need.

\section{NEEDS ANALYSIS ON BUSINESS ENGLISH LEARNERS}

Needs Analysis refers to such methods as introspection, interviews, questionnaires and so on so forth that can be carried out to investigate the needs of the target object. Target Situation Analysis (TSA), proposed by Hutchinson and Waters (1987), can be employed to investigate the future requirements and to which the learners' attitudes. While Present Situation Analysis (PSA), put forward by Allwright (1982), can be used to spot learners' current deficiency in knowledge and skills. And Learning Situation Analysis (LSA), mentioned by Hutchinson and Waters (1987), includes teaching resources, learners' knowledge, skills, study strategies and learning motivation. "Just as no medical intervention would be prescribed before a thorough diagnosis of what ails the patient, so no language teaching program should be designed without a thorough needs analysis" (Long, 2005, p.1) Similarly, words serve as fundamental bricks for learners to learn a foreign language and the acquisition of business terms is the first step for BE learners to have further study on business related knowledge. Therefore, only if the BE learners' needs are clearly observed and taken into consideration, can compilers develop an electronic dictionary that is of great help for them on going through the 4-year courses in an efficient and effective way.

This survey was conducted on full-time undergraduate students who were business English majors and international business majors in the School of International Business English at Guangdong University of Foreign Studies in June

\footnotetext{
* This research was supported by the Graduate Program of Scientific Research and Innovation in Guangdong University of Foreign Studies (Grant No.17GWCXXM-52).
} 
2017. The reason why business English majors and international business majors in International Business English Program at Guangdong University of Foreign Studies were chosen as study subjects is because that the SEIB in GDUFS is the first one in China to launch the Business English program on the undergraduate, postgraduate and doctorial levels, hence, those business English majors and international business majors can be regarded as representatives of the majority of BE learners in China.

The questionnaire was designed based upon previous interview findings and 254 questionnaires were issued and collected and 254 were valid.130 were business English majors and 124 were international business majors, and 60 freshmen, 67 sophomores, 70 juniors and 57 seniors. This questionnaire was designed to study the needs of BE learners on business terms study and serve as reference for compilers to build a more BE-learner-friendly specialized electronic dictionary for Chinese BE learners.

Questions involved in the questionnaire and interview, including one-choice questions, multiple-choice questions and open questions, were designed based on such kinds of analysis mentioned above as Target Situation Analysis (TSA), Present Situation Analysis (PSA) and Learning Situation Analysis (LSA) to study (1) the relation considered by BE learners between the acquisition of business terms and that of business related knowledge; (2) current deficiency of BE learners in business term knowledge; (3) the objective conditions that limit the effective acquisition of business terms; (4) the current situation of the usage of electronic dictionary of BE learners; (5) the disadvantages of electronic dictionary in terms of business term study; (6) requirements on further function and information concerning business terms that are expected to be provided by electronic dictionary.

\section{FINDINGS}

With the analysis of the data drawn from the questionnaire attached, this part discusses the findings from the needs of $\mathrm{BE}$ learners on business terms study and the disadvantages of existing electronic dictionaries so as to pave the way for the further suggestions on building a specialized C-E/ E-C electronic dictionary for Chinese BE learners

\section{A. Needs of Business English Learners on Business Terms Study}

"Learners were seen to have different needs and interests, which would have an important influence on their motivation to learn and therefore on the effectiveness of their learning" (Hutchinson et al., 1987, p.8). Compared with other English learners, BE learners have their own specific needs on learning English, especially for the acquisition of business terms. Therefore, it is needed to see what is the current situation of these students and what are the needs required to be met.

(1) There are few statistically differences between the needs of business English majors and international business majors in SEIB, while there are some differences among their needs from different grades. The author sets the first and second questions to collect the background information of majors and grades of the objects, aiming to explore whether there are different needs between business English majors and international business majors and among that from 4 grades. The differences will be demonstrated and expounded in corresponding paragraphs.

(2) Majority of BE learners reckons that there are close and significant relation between the acquisition of business terms and that of business related knowledge. The study shows that $94.49 \%$ of the study subjects (showed in Q3) reckons that it is needed to attach great importance to the accumulation of the knowledge of business terms at their current stage, which means that business terms are always on the top of the list for BE learners at each grade and they can never stop acquiring them during their 4-year-studying process. In addition, over 95.66\% of BE learners (showed in Q5) do not think they have accumulated enough knowledge of business terms at the current stage. And accordingly, it can arrive at the reason why $63.39 \%$ of them (showed in Q6), claims that they feel difficult when studying business courses and $94.88 \%$ (showed in Q7) insists that the previous accumulation of business terms can be of great help on studying those courses.

TABLE 1

Q3. DO YOU THINK IT IS NEEDED TO ATTACH GREAT IMPORTANCE TO THE ACCUMULATION OF THE KNOWLEDGE OF BUSINESS TERMS AT THIS STAGE?

\begin{tabular}{ll}
\hline Option & Percentage \\
\hline A. yes & $94.49 \%$ \\
B. no & $3 \%$ \\
\hline & \multicolumn{1}{c}{ TABLE 2} \\
Q5. Do YOU THINK YOU HAVE ACCUMULATED ENOUGH KNOWLEDGE OF BUSINESS TERMS AT THIS STAGE? \\
\hline Option & Percentage \\
\hline A. not enough & $40.94 \%$ \\
B. not very enough & $54.72 \%$ \\
C. relative enough & $3.94 \%$ \\
D. enough & $0.39 \%$ \\
\hline
\end{tabular}


TABLE 3

Q6. DO YOU FEEL DIFFICULT WHEN STUDYING BUSINESS COURSES?

\begin{tabular}{ll}
\hline Option & Percentage \\
\hline A. not difficult & $1.57 \%$ \\
B. not very difficult & $20.87 \%$ \\
C. relative difficult & $53.94 \%$ \\
D. very difficult & $9.45 \%$ \\
E. did not attend these courses & $14.17 \%$ \\
\hline
\end{tabular}

TABLE 4

Q7. DO YOU THINK THE PREVIOUS ACCUMULATION OF KNOWLEDGE OF BUSINESS TERMS CAN BE OF GREAT HELP ON STUDYING BUSINESS COURSES?

\begin{tabular}{ll}
\hline Option & Percentage \\
\hline A. yes & $94.88 \%$ \\
B. no & $5.12 \%$ \\
\hline
\end{tabular}

(3) BE students think they should pay more attention on the study of Chinese/English equivalents, disciplines and application fields, collocation and direction, encyclopedic information in Chinese, and encyclopedic information in English, and at the meanwhile, they should focus the most on disciplines and application fields (76.38\%) and the least on pronunciation $(28.35 \%$ ) of business term. Besides, as they have stepped to the next studying stage, fewer and fewer of them, showed in table 6, would focus on pronunciation. The study also shows (in Q8) that $69.69 \%$ considers that it is hard to distinguish the business meanings from a general word and the different usages of synonymous business terms. And $53.15 \%$ thinks they merely know the simple translation of business terms without knowing the application situations, 52.76\% merely know the Chinese/English equivalent of the business terms and $40.94 \%$ feels it is hard to handle the meaning of business terms itself. This shows the difficulty on learning business term itself.

TABLE 5

Q4. THE KNOWLEDGE OF BUSINESS TERMS AT THIS STAGE SHOULD BE FOCUS ON

\begin{tabular}{ll}
\hline Option & Percentage \\
\hline A. pronunciation & $28.35 \%$ \\
B. Chinese/English equivalents & $64.57 \%$ \\
C. disciplines and application fields & $76.38 \%$ \\
D. collocation and direction & $71.26 \%$ \\
E. encyclopedic information in Chinese & $53.94 \%$ \\
F. encyclopedic information in English & $62.2 \%$ \\
G. others & $1.18 \%$ \\
\hline
\end{tabular}

TABLE 6

\begin{tabular}{|l|l|l|l|l|}
\hline $\mathrm{X} Y$ & Freshman & Sophomore & Junior & Senior \\
\hline pronunciation & $53.33 \%$ & $29.85 \%$ & $18.57 \%$ & $10.53 \%$ \\
\hline
\end{tabular}

TABLE 7

Q8. THE DEFICIENCIES ON THE MASTERING OF BUSINESS TERMS THAT YOU THINK YOU HAVE ARE

\begin{tabular}{lc}
\hline Option & Percentage \\
\hline A. hard to handle the meaning of business terms itself & $40.94 \%$ \\
B. hard to distinguish the business meanings from a general word & $69.69 \%$ \\
C. merely know the Chinese/English equivalent of the business terms & $52.76 \%$ \\
D. merely know the simple translation of business terms without knowing the application situations & $53.15 \%$ \\
E. hard to distinguish different usages of synonymous business terms & $69.69 \%$ \\
F. no deficiencies & $1.18 \%$ \\
G. others & $0.79 \%$ \\
\hline
\end{tabular}

(4) Though business-term-learning process is obscure and hard to master, BE learners think the difficulty is also caused by the shortage of available additional learning materials that can be of significant support during the learning process. The study shows from Q9 that students think that the reason why they failed to learn business terms effectively, to a great extent, is because that the meanings of many business terms are close to each other (73.62\%), it is hard to tell them apart and those terms are required to be used in specific situations with strict standards (73.62\%). What's more, the features like wide range of fields $(67.32 \%)$ and obscure connotations $(51.18 \%)$ of business terms also win many votes. Compared with the difficulties brought by the business term itself, the objective condition like the shortage of learning materials concerning the knowledge of business terms, which accounts for $86.61 \%$, wins the most votes for hindering BE learners from learning business terms effectively. What's more, the reason of scattered online resources takes up $60.24 \%$ and the reason of current dictionaries failing to provide needed information occupies $51.97 \%$, which also indicates that there are plenty of work could be done to better support BE learners. 
TABLE 8

Q9. THE DIFFICULTIES OF BUSINESS TERMS THAT HINDER YOU FROM LEARNING BUSINESS TERMS EFFECTIVELY ARE

\begin{tabular}{ll}
\hline Option & Percentage \\
\hline A. business terms cover a wide range of fields & $67.32 \%$ \\
B. business term itself is obscure and hard to master & $51.18 \%$ \\
C. the meanings of many business terms are close to each other and hard to tell & $73.62 \%$ \\
D. business terms are required to be used in specific situations with strict standards & $73.62 \%$ \\
E. no difficulties & $1.18 \%$ \\
F. others & $0 \%$ \\
\hline
\end{tabular}

TABLE 9

Q10. THE OBJECTIVE CONDITIONS THAT HINDER YOU FROM LEARNING BUSINESS TERMS EFFECTIVELY ARE

\begin{tabular}{ll}
\hline Option & Percentage \\
\hline A. the attached glossary of business terms in textbook is too simple & $38.98 \%$ \\
B. lacking learning materials concerning the knowledge of business terms & $86.61 \%$ \\
C. current dictionaries fail to provided needed information & $51.97 \%$ \\
D. related online resources are scattered & $60.24 \%$ \\
E. others & $2.36 \%$ \\
\hline
\end{tabular}

(5) Such information concerning business terms as belonged disciplines or fields (74.41\%), encyclopaedic information (70.47\%), Chinese/English equivalents (60.02\%), English definition (65.75\%), Chinese definition (58.66\%), sentence examples $(48.43 \%)$, and differentiation among synonyms/antonyms $(44.09 \%)$ are highly required by BE learners, while the pronunciation (37.4\%) and synonyms and antonyms of business terms $(38.58 \%)$ are in rather low demand (showed in Q11). Still, students at higher grades tend to attach greater importance to the encyclopaedic information while less to the pronunciation about business terms.

TABLE 10

Q11. WHEN LOOKING BUSINESS TERMS UP IN A DICTIONARY, YOU WANT TO OBTAIN SUCH INFORMATION AS__-_

\begin{tabular}{ll}
\hline Option & Percentage \\
\hline A. pronunciation & $37.4 \%$ \\
B. belonged disciplines or fields & $74.41 \%$ \\
C. Chinese/English equivalents & $60.02 \%$ \\
D. Chinese definition & $58.66 \%$ \\
E. English definition & $65.75 \%$ \\
F. synonyms/antonyms & $38.58 \%$ \\
G. differentiation among synonyms/antonyms & $44.09 \%$ \\
H. encyclopedic information & $70.47 \%$ \\
I. sentence examples & $48.43 \%$ \\
J. others & $0.79 \%$ \\
\hline
\end{tabular}

(6) The application of electronic dictionary has become a heated trend for BE learners when they are trying to search business terms. In addition, they expect that electronic dictionary can serve to be of great help for them to acquire business terms, as well. When looking business terms up in a dictionary, 93.31\% of BE students (showed in question 12) would choose electronic dictionaries. What's more, $91.14 \%$ of them regards convenience, $79.32 \%$, timely update of the word library, $69.62 \%$, rich information resources and $62.03 \%$, strong connectivity among related information (showed in question 14), as its superior advantages.

TABLE 11

Q12. WHEN LOOKING BUSINESS TERMS UP IN A DICTIONARY, YOU TEND TO CHOOSE

\begin{tabular}{ll}
\hline Option & Percentage \\
\hline A. printed dictionary & $6.69 \%$ \\
B. electronic dictionary & $93.31 \%$ \\
\hline
\end{tabular}

TABLE 12

Q14. WHEN LOOKING BUSINESS TERMS UP IN A DICTIONARY, YOU THINK, COMPARED WITH PRINTED DICTIONARY, THE ADVANTAGES OF ELECTRONIC DICTIONARY ARE ____ (THIS QUESTION WOULD BE ANSWERED BY STUDENTS WHO CHOOSE “B” AT Q12)

\begin{tabular}{ll}
\hline Option & Percentage \\
\hline A. convenience & $91.14 \%$ \\
B. almost all the target words can be found & $48.52 \%$ \\
C. the word library can be updated timely & $79.32 \%$ \\
D. rich information resources & $69.62 \%$ \\
E. strong connectivity among related information & $62.03 \%$ \\
F. others & $0.84 \%$ \\
\hline
\end{tabular}

Therefore, during the learning process, in which the focus is shifted from acquiring knowledge of English to studying concepts of business in English, Business English (BE) learners need a specialized C-E/E-C electronic dictionary so that their business related knowledge can be structured efficiently and effectively.

\section{B. Disadvantages of Existing Electronic Dictionaries}

The electronic dictionary mentioned in this paper mainly refers to online dictionary and offline dictionary (like apps). 
"The term electronic dictionary (or ED) can be used to refer to any reference material stored in electronic form that gives information about the spelling, meaning, or use of words" (Hilary et al., 2000, p.839) Nowadays, in order to acquire the knowledge of business terms, BE learners in China are able to choose such mainstream electronic dictionaries "Adopts the users' perspective and investigates the effectiveness of electronic dictionaries for different categories of users, in particular students and translators" (Granger, 2012, p.12). It cannot be denied that those electronic dictionaries are well-developed for English learners in China. However, it could be concluded from Q13 and Q15 that they do have some disadvantages when being employed during the learning process by BE learners.

TABLE 13

Q13. WHEN LOOKING BUSINESS TERMS UP IN A DICTIONARY, YOU THINK, COMPARED WITH PRINTED DICTIONARY, THE DISADVANTAGES OF ELECTRONIC DICTIONARY ARE ____ (THIS QUESTION WOULD BE ANSWERED BY STUDENTS WHO CHOOSE “A” AT Q12)

\begin{tabular}{ll}
\hline Option & Percentage \\
\hline A. cannot find the target word & $41.18 \%$ \\
B. information provided is unprofessional & $70.59 \%$ \\
C. directions are not expounded in detail & $64.71 \%$ \\
D. the arrangement of information is messy & $23.53 \%$ \\
E. no differentiation among synonyms/antonyms & $17.65 \%$ \\
F. others & $0 \%$ \\
\hline
\end{tabular}

TABLE 14

Q15. PROBLEMS ENCOUNTERED WHEN LOOKING BUSINESS TERMS UP IN AN ELECTRONIC DICTIONARY ARE

\begin{tabular}{l|l}
\hline Option & Percentage \\
\hline A. cannot find the target word & $40.94 \%$ \\
\hline B. too much information and the information arrangement is messy and even overlapping & $72.44 \%$ \\
\hline C. information resources are not reliable and sometimes there are some mistakes & $84.25 \%$ \\
\hline D. business meanings of general words were not collected sometimes & $72.83 \%$ \\
\hline E. disciplines of business terms were not tagged sometimes & $70.87 \%$ \\
\hline F. merely Chinese/English equivalents were provided sometimes & $70.87 \%$ \\
\hline $\begin{array}{l}\text { G. general meanings and business meanings of a general word were gathered together, which leads to time-consuming } \\
\text { searching process }\end{array}$ & $76.77 \%$ \\
\hline H. no differentiation provided among synonyms/antonyms & $64.57 \%$ \\
\hline I. no encyclopedic information and it's needed to further baidu the definition of target business term & $65.35 \%$ \\
\hline J. others & $0.39 \%$ \\
\hline
\end{tabular}

(1) Existing electronic dictionaries are developed to satisfy the needs of all users rather than to merely emphasize on the demands of BE learners. They manage to gather huge number of vocabulary and example sentences through all kinds of electronic resources to ensure that each user can, at least, find the equivalents, definitions and examples of his or her target words. Nonetheless, they try to satisfy the needs of learners from all walks of life, but it turns out that they cannot perfectly meet the demands of everyone, which vary from person to person. As a consequence, for BE learners, these mainstream electronic dictionaries can only serve the basic needs of looking simple equivalents of words up, since the general and specialized definitions of a certain word are mixed together, some miss the specialized meanings that this word contains and some even do not mark which subject this word belongs to.

(2) The knowledge that BE learners is provided by existing electronic dictionaries is fragmented, overlapped and even unprofessional information. Some BE terms merely have their Chinese or English equivalents and lack the further definitions and examples. In addition, although developers tend to share interesting and valuable Business English related news and articles with BE learners, those contents are fragmented rather than being systematically composed. And what BE learners is able to obtain from those news and articles is business related information rather than knowledge. Besides, equivalents, definitions and examples are gathered and displayed separately without a unified and systematic arrangement. In order to provide all-round and professional information of a word, these electronic dictionaries combine their own equivalents and definitions of a certain word with that from different kinds of dictionaries and websites together rather than integrate these information and delete the overlapped parts. In order to look a business term up in these existing electronic dictionaries, it is needed for BE learners to click link to link and sometimes there is even no approving results displayed on the screen. Hence, this may lead to a time-consuming searching process and make it harder for BE learners to find out the knowledge they long for efficiently and effectively.

(3) There is no explanation and comparison among synonymous business terms. The information of synonymous business terms is displayed in existing electronic dictionaries in an isolated way. In addition, even if BE learners look target terms up in these electronic dictionaries respectively, it is hard to spot the differences between these words. However, it is the differences of different entries, whether Chinese one or English one, that matters significantly in economic activities. In business situation, there are not only specific words but also general words with business meanings that are employed as Business English terms in different business situations. What's more, in certain cases, different business terms may have the same Chinese expression but they are required to be applied in different situations. These concepts are clear for experienced businessman, while ambiguous for callow BE learners. Therefore, this confusion of concepts may become a barrier for BE learners to integrate their knowledge and practice. And it is needed for those specialized electronic dictionaries to offer explanation and comparison among synonymous business terms for BE learners. 


\section{SugGestions}

As the paper has analysed above that existing electronic dictionaries have their disadvantages and cannot fully satisfy the needs of BE learners. Then it is significant to build a specialized electronic dictionary of C-E/E-C according to the needs of BE learners and the features of BE terms.

TABLE 15

Q16. YOU EXPECT THAT ELECTRONIC DICTIONARIES CAN ADD SUCH INFORMATION AND FUNCTIONS AS____

\begin{tabular}{ll}
\hline Option & Percentage \\
\hline A. belonged disciplines and fields & $66.54 \%$ \\
B. words used in the same register & $70.08 \%$ \\
C. differentiation among synonyms/antonyms & $50.00 \%$ \\
D. charts or tables serving to further explain some business terms & $60.63 \%$ \\
E. links to the encyclopedic information of the business term & $66.54 \%$ \\
F. others & $1.57 \%$ \\
\hline
\end{tabular}

The focus is still on user-friendly, while it is supposed to be narrowed down to the perspective of BE learners. For BE learners, their needs is far beyond more words and more interesting functions. "Effective Second Language Acquisition (SLA) needs the assistance of new generation teaching dictionaries. And being encyclopaedic and specific are significant direction for future teaching dictionaries development" (Zhang, 2009, p.36). Therefore, during this learning process, the BE learners need a specialized C-E/E-C electronic dictionary that can serve as an encyclopaedia to help them to form their business related knowledge structure so as to digest those intricate knowledge efficiently and effectively in future study. And the suggestions on building a customized electronic dictionary of C-E/E-C business terms for BE learners are as follows:

(1) Building a professional and specialized database. In order to build a professional and specific database, it requires the focus on the dictionary itself and the coordination among developers, lexicographers and professionals from general English teaching and Business English teaching. "In mainland China, electronic dictionaries were developed with electronic technology as basis. Products in early period were developed independently by information technology enterprises, and their commercial object was evident" (Zhang, 2007, p.4).

Nowadays, though developers have invited professionals to work on compiling dictionary together, they pay more attention to develop extra attractive functions rather than to the dictionary itself, and their emphasis is still on attracting visitors, drawing investments and increasing profits. Moreover, It is required to ensure that BE learners can, at least, find the Chinese definitions of his or her target words. "The invention of wiki technology has brought about one of the most spectacular changes in lexicography, i.e. the integration of collaborative or community-based input" (Granger, 2012, p.6) The developers of these dictionaries can also invite learned users to offer definitions for words without authorized definitions. In this way, so long as BE learners look their target words up in the dictionary, there would demonstrate relevant definitions and sentence examples.

(2) Besides, updating timely is significant for a specialized C-E/E-C electronic dictionary in that business terms need to be updated every now and then so that it can catch up with the development trend of economy and technology in this information age. What's more, since business covers a wide range of fields, there generated a great diversity of terms derived from those fields. "(International) Business English, an inter-discipline program, takes English as the carrier and linguistics, management, economics, science of law and psychology as major courses” (Zhang et al., 2008, p.103).

According to Oxford Business English Dictionary for Learners of English, which was published by Huaxia Publishing House in 2011, business terms can be further divided into following subjects as accounting, commerce, economics, HR, insurance, IT, law, marketing, stock exchange, technical, transport, etc. And Fuertes-Olivera (2012, p.404) reckons that "business/economics is a very broad subject field that can be broken down into around forty different sub-fields." And it is due to this feature, the collection of BE terms are required to vacuum up the newest information and snap the representative terms so as to enable BE learners to keep pace with the changing times.

(3) It is also supposed to group terms that will be applied in the same register and provide learners with specialized equivalents, detailed definitions and practical examples. In order to provide learners with specialized equivalents, detailed definitions and practical examples, it is needed to combine resources from existing printed dictionaries, electronic dictionaries and learning websites with prudent selection and systematic arrangement. "Usually, the study of lexicography does not include the practical needs and cognitive ability of dictionary users, which, to a great extent, would influence the using effect of dictionaries" (Huang et al., 2008, p.90).

From the perspective of BE learners, this dictionary, firstly is developed to directly provide BE learners with a specialized and professional equivalents for those classic business terms and general words with business meanings. And then it offers detailed definitions and practical examples so as to help BE learners to obtain the information of target terms in an effective and efficient way. It may be able to, accordingly, be of great help on the knowledge construction phase of BE learners. "During the translation process of law related terms, the mere reference of general bilingual dictionaries is not enough. It is necessary to look them up in specialized Chinese and foreign language dictionaries" (Zhang, 1997, p.68).

(4) Moreover, making comparison among synonymous business terms for BE learners is of great importance. In business situation, there are not only specific words but also general words with business meanings are employed as 
Business English terms. In addition, both specific and general content of a certain word would be involved. "Business English is usually presented as a hybrid that mixes specific and general content and is concerned with the teaching and learning of the strategic communication system in the business domain" (Fuertes-Olivera, 2012, p.402). And because business activities are carried out in different and specific situation, it can be sure that the definition of a business term is certain so long as it is properly used in that situation.

In order to make comparison among synonymous business terms for BE learners, the professional guidance of professionals who study on BE teaching and BE practicing is required. It cannot be denied that merely professionals of general English cannot distinguish clearly words from words applied in business situation in that Business English covers a wide range of fields and business terms are of great specialty, like jargon. Therefore, this requires the assistance of teachers who are familiar with business concepts and are experts at BE teaching as well.

\section{CONCLUSION}

Nowadays, it cannot be denied that those mainstream C-E/E-C electronic dictionaries have been well-developed in China. However, they do have some disadvantages when being employed by BE learners during the learning process and a specialized C-E/E-C dictionary for Chinese business English learner is in great need. This paper studies what improvements are required to be done by the developers from the perspective of BE learners. Further study is suggested to be focused on those specific business terms, for business term itself is the core of the specialized electronic dictionary. Especially for the standardised translation of business English terms, standardised definition and translation of business Chinese terms, and business meanings of general words, phrases and collocations as well.

\section{APPENDIX}

\section{商务英语专业及国际商务专业学生商务术语学习需求和电子词典使用情况调查}

本问卷旨在对我院 (广东外语外贸大学国际商务英语学院) 商务英语专业及国际商务专业学生的商务术语学 习需求和电子词典使用情况进行调查。希望本次调查结果能对未来电子词典的发展以及商务英语专业和国际商 务专业学习者在商务术语上的学习有所帮助。本问卷仅用于科研学术研究, 对于个人信息我们将严格保密, 请 您根据自己的实际情况放心填写。非常感谢您于百忙之中抽出时间填写调查问卷!

说明: 1. 商务术语: 指在商务场合中使用的具有商务专业特色的词汇, 包含专有名词以及具有商务含义的普 通词汇 (如: future n. 通义为: 未来; 商义为: 【证券交易】期货）。2. 电子词典: 指能提供中英文释义的网 络在线词典以及离线词典 App。（如: 有道、海词、金山词霸、必应等）3. “【】”为学科标注符号，如: 【证 券交易】。

第 1 题 你的专业是 [单选题]

A. 商务英语专业

B. 国际商务专业

第 2 题 你所在的年级是

A. 大一

B. 大二

C. 大三

D. 大四

第 3 题 你认为现阶段是否应该注重商务术语知识的积累 [单选题]

A. 是

B. 否

第 4 题 你认为该阶段商务术语知识的学习重点应放在 [多选题]
A. 术语的语音
B. 术语的简单中/英文对应词
C. 术语的学科分类及使用领域
D. 术语的用法及搭配
E. 术语的中文百科知识信息
F. 术语的英文百科知识信息
G. 其它

第 5 题 你觉得自己现阶段商务术语知识的储备如何 [单选题]
A. 不充分
B. 不太充分
C. 较为充分
D. 很充分 
第 6 题 在学习商务专业课 (如会计学、营销学、管理学等) 时, 是否感觉吃力 [单选题]
A. 不吃力
B. 不太吃力
C. 有点吃力
D. 很吃力
E. 还没上这些课

第 7 题 你认为前期对商务术语知识的积累是否能够有助于后期商务专业课的学习 [单选题]
A. 是
B. 否

第 8 题 你觉得自己在商务术语知识的掌握上有哪些不足 [多选题]
A. 难以掌握商务术语本身的意思
B. 难以辨认普通词汇的商务含义
C. 只知道术语的简单中/英文对应词但不知道其背后的含义
D. 只知道术语的简单释义但不知道其使用领域及场合
E. 难以区分各个术语近义词的不同用法
F. 没有不足
G. 其它
第 9 题 你认为学习商务术语知识的难点在于 [多选题]
A. 商务术语涉及领域广
B. 商务术语本身晦澀难懂
C. 许多商务术语概念接近, 易混淆
D. 商务术语有限定的使用场合，使用标准严格
E. 无难点
F. 其它

第 10 题 你认为限制你有效学习商务术语知识的客观条件在于 [多选题]

A. 课本里所附的术语表过于简单

B. 缺乏对这方面具有针对性的学习材料

C. 现有词典无法提供所需的知识信息

D. 与此相关的网络信息资源较为分散

E. 其他

第 11 题 在查阅商务术语时, 你希望能从词典中获取哪些信息 [多选题]
A. 术语的发音
B. 术语所属的学科或领域
C. 术语的简单中/英文对应词
D. 术语的中文释义
E. 术语的英文释义
F. 术语的近/反义词
G. 术语的近/反义词辨析
H. 术语的百科知识信息

I. 相应的例句

J. 其它

第 12 题 在查阅商务术语时, 你更倾向于使用纸质词典还是电子词典 [单选题]
A. 纸质词典
B. 电子词典

第 13 题 在查阅商务术语时, 你认为电子词典的劣势在于 [多选题]
A. 有时查不到想查的词
B. 信息不够权威
C. 用法不够详细
D. 信息排列重复、杂乱
E. 无近义词辨析
F. 其他
第 14 题 在查阅商务术语时, 你认为电子词典的优势在于 [多选题]

A. 使用便利 
B. 想查的词基本都查得到

C. 词库可随时更新, 词量更丰富

D. 信息来源广

E. 相关信息之间的链接性强

F. 其他

第 15 题 在使用电子词典查询商务术语时遇到的问题有 [多选题]

A. 有时想查的词查不到

B. 信息量大, 分布杂乱且有重复现象

C. 信息来源不可靠, 有时甚至有错误

D. 有时存在未收录普通词汇的商务释义的情况

E. 有时存在未对某些商务术语所属的学科进行标注的情况

F. 有时仅提供术语简单的中/英文对应词

G. 普通词汇的通义与商义混放, 检索过程耗时

H. 无近/反义词辨析

I. 无术语的百科知识信息, 查到词的意思后仍需进一步百度释义

J. 其它

第 16 题 希望电子词典增添哪些信息或功能 [多选题]

A. 提供该术语所属的学科信息

B. 提供与该术语属同一语域的词汇信息

C. 提供近/反义词辨析

D. 对某些特定术语附以图表进行解释

E. 链接术语的百科知识信息

F. 其它

第 17 题 为了能更好的满足商务英语/国际商务专业学生的需求, 你对现有电子词典有哪些改进建议? [选 填题]

\section{REFERENCES}

[1] Allright, R. (1982). Perceiving and pursuing learner's needs. In Geddes, M. \& Sturtridge, G. (eds.), Individualization. Oxford: Modern English Publications, 24-31.

[2] Fuertes-Olivera, P. A. (2012). On the usability of free Internet dictionaries for teaching and learning Business English, In Granger, S. \& Paquot, M. (eds.), Electronic Lexicography. Oxford: Oxford University Press, 399-424.

[3] Granger, S. (2012). Electronic lexicography: From challenge to opportunity. In Granger, S. \& Paquot, M. (eds.), Electronic Lexicography. Oxford: Oxford University Press, 1-11.

[4] Huang Qunying \& Zhang Yihua. (2008). Towards the Interactive Relation between Definitions and Dictionary Users. Journal of Guangdong University of Foreign Studies, 03: 90-94.

[5] Hutchinson, T. \& Waters, A. (1987). English for specific purposes - a Learning-centered Approach. Cambridge University Press, Cambridge.

[6] Long, M. H. (2005). Second Language Needs Analysis. London: Cambridge University Press. http://dx.doi.org/10.1017/CBO9780511667299.

[7] Nesi, H. (2000). Electronic Dictionaries in Second Language Vocabulary Comprehension and Acquisition: The State of the Art. In Heid, U., Evert, S., Lehmann, E. \& Rohrer, C. (eds.), Proceedings of the Ninth Euralex International Congress, EURALEX 2000. Stuttgart: Universita"t Stuttgart, 839-847.

[8] Zhang Jinwen. (1997). Term Translation and the Application of Specialized Monolingual Dictionaries. Lexicographical Studies, 06: 67-69.

[9] Zhang Wubao. (2011). On the Origin and Dynamic Model of Business English Program. Journal of North China University of Water Resources and Electric Power (Social Science Edition), 03: 7-10.

[10] Zhang Wubao \& Yan Xinsheng. (2008). Academic Innovation and the Integrated Quality of Business English. Journal of Guangdong University of Foreign Studies, 02: 101-104.

[11] Zhang Yihua. (2007). On Development Strategies of Electronic Dictionaries in China. Lexicographical Studies, 02: 1-11.

[12] Zhang Yihua. (2009). On Bilingual Teaching and Specialized Learning Dictionaries - Taking English-Chinese Dictionaries as Examples. Foreign Language World, 04: 30-37.

[13] Zhong Weihe, Zhang Wubao \& He Jianing. (2015). On Positioning BA in Business English Program in Higher Education. Foreign Languages in China, 01: 4-10.

Zhiyi Zhou was born in Liupanshui, China in 1995. She is now a postgraduate student in the school of international business English, Guangdong University of Foreign Studies, Canton, China and her research interests are business English language and business English teaching. 